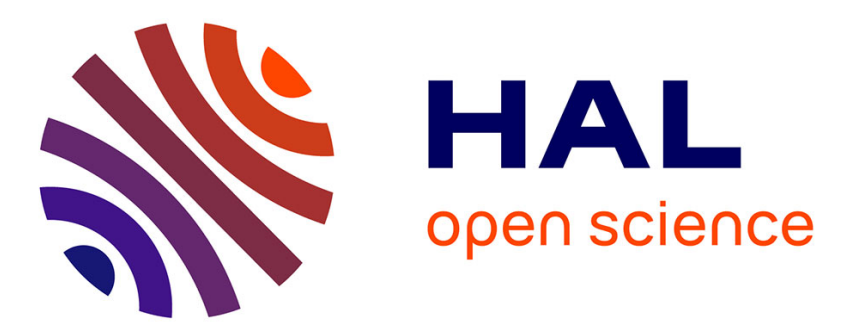

\title{
Redox evolution of a degassing magma rising to the surface.
}

Alain Burgisser, Bruno Scaillet

\section{To cite this version:}

Alain Burgisser, Bruno Scaillet. Redox evolution of a degassing magma rising to the surface.. Nature, 2007, 445, pp.194-205. 10.1038/nature05509 . hal-00125264

\section{HAL Id: hal-00125264 \\ https://hal-insu.archives-ouvertes.fr/hal-00125264}

Submitted on 23 Jul 2007

HAL is a multi-disciplinary open access archive for the deposit and dissemination of scientific research documents, whether they are published or not. The documents may come from teaching and research institutions in France or abroad, or from public or private research centers.
L'archive ouverte pluridisciplinaire HAL, est destinée au dépôt et à la diffusion de documents scientifiques de niveau recherche, publiés ou non, émanant des établissements d'enseignement et de recherche français ou étrangers, des laboratoires publics ou privés. 
Redox evolution of a degassing magma rising to the surface

\section{Alain Burgisser and Bruno Scaillet}

burgisse@cnrs-orleans.fr

bscaille@cnrs-orleans.fr

ISTO-CNRS, 1a rue de la Férollerie, 45071 Orléans cedex 2, France

main text : 1828 words

abstract : 279 Words

29 references

3 figures, 1 table

Supplementary Information

Volatiles carried by magmas, either dissolved or exsolved, exert a fundamental role on a variety of geological phenomena such as magma dynamics ${ }^{1-5}$ or the composition of Earth's atmosphere ${ }^{6}$. In particular, the redox state of volcanic gases emanating at the Earth surface is widely believed to mirror that of their magma source, and thought to have exerted a first order control on the secular evolution of atmospheric oxygen $^{6-7}$. However, $\mathrm{fO}_{2}$ estimates retrieved from lava or gas chemistry may differ by as much as one $\log$ unit $^{8-10}$, the reason of such a difference remaining obscure. Here, by using a coupled chemical-physical model of conduit flow, we show that the redox state evolution of an ascending magma, and thus of its coexisting gas phase, is strongly dependent on both the composition and amount of gas in the reservoir. Magmas with no sulphur show a systematic $\mathrm{fO}_{2}$ increase during ascent, by as much as 
2 log units. Magmas with sulphur show also a change of redox state during ascent, but the direction of change depends on the initial $\mathrm{fO}_{2}$ in the reservoir. Our calculations closely reproduce the $\mathrm{H}_{2} \mathrm{~S} / \mathrm{SO}_{2}$ ratios of volcanic gases observed at convergent settings, yet the difference between $\mathrm{fO}_{2}$ in the reservoir and that at the exit of the volcanic conduit may be as much as $1.5 \log$ unit. This $\mathrm{fO}_{2}$ evolution provides one explanation for the apparent conflict documented between lava and gas based $\mathrm{fO}_{2}$ estimates. We thus conclude that the redox state of erupted magmas is not necessarily a good proxy of the redox state of the gases they emit. Our findings may require re-evaluation of current models aimed at quantifying the role of magmatic volatiles on geological processes.

Recent studies have investigated the role of redox equilibria during volatile exsolution but the solution of the numerical problem requires fixing either iron or sulphur redox states ${ }^{11}$ : as a result, the effect of decompression on oxygen fugacity $\left(f \mathrm{O}_{2}\right)$ cannot be evaluated. In the present work, we relax such an assumption by taking advantage of the fact that the solubility laws of key volatile species other than $\mathrm{H}_{2} \mathrm{O}$ and $\mathrm{CO}_{2}$ have been recently determined, in particular that of $\mathrm{H}_{2}, \mathrm{SO}_{2}$, and $\mathrm{H}_{2} \mathrm{~S}{ }^{12,13}$. In this work we considered gas phases in the system $\mathrm{H}-\mathrm{O}-\mathrm{S}$, with 6 species $\left(\mathrm{H}_{2} \mathrm{O}, \mathrm{H}_{2}, \mathrm{SO}_{2}, \mathrm{H}_{2} \mathrm{~S}, \mathrm{~S}_{2}\right.$, and $\left.\mathrm{O}_{2}\right)$ in which the following redox equilibria occur:

$$
\begin{aligned}
& \mathrm{H}_{2}+1 / 2 \mathrm{O}_{2}=\mathrm{H}_{2} \mathrm{O} \\
& \mathrm{H}_{2} \mathrm{~S}+1 / 2 \mathrm{O}_{2}=\mathrm{H}_{2} \mathrm{O}+1 / 2 \mathrm{~S}_{2} \\
& \mathrm{O}_{2}+1 / 2 \mathrm{~S}_{2}=\mathrm{SO}_{2}
\end{aligned}
$$


Standard thermodynamic considerations ${ }^{14,15}$ show that once total pressure, $\mathrm{P}$, temperature, $\mathrm{T}$, and two additional intensive parameters such as water and hydrogen fugacities $\left(f \mathrm{H}_{2} \mathrm{O}\right.$ and $\left.f \mathrm{H}_{2}\right)$ are known, the fugacities of all remaining species $\left(f \mathrm{H}_{2} \mathrm{~S}, f \mathrm{O}_{2}, f \mathrm{~S}_{2}, f \mathrm{SO}_{2}\right)$ are fixed and the gas phase composition in the H-O-S system is fully determined. Each species $i$ in the gas has a mole fraction $m_{i}$ :

$$
\Sigma m_{i}=1
$$

The gas phase is modelled as an ideal mixture of non-ideal gases, a valid approximation in the pressure range considered here. Departure from ideal behaviour of end-member species is accounted for by the fugacity coefficient $\gamma_{\mathrm{i}}$ which is fixed by $\mathrm{P}$ and $\mathrm{T}^{16}$. The total weight fraction of each species $\left(w_{T i}\right)$ is the sum of its exsolved part $\left(w_{g i}\right)$ and its dissolved part:

$$
w_{T i}=w_{g i}+a_{i}\left(\gamma_{i} m_{i} P\right)^{b i}
$$

where $a_{i}$ and $b_{i}$ are solubility constants experimentally determined (Table 1). We use a homogeneous, one-dimensional conduit flow $\operatorname{model}^{5}$ to simulate magma ascent under closed system and equilibrium conditions. Magma rises in a cylindrical conduit at constant mass flux and volatile exsolution affects the flow through changes in buoyancy and viscosity (cf. Supplementary Information). Calculations are performed by first fixing $P, T$, $\mathrm{fH}_{2} \mathrm{O} f \mathrm{H}_{2}$, and the amount of gas in the reservoir. The model seeks first the equilibrium distribution of each volatile species between gas and melt prior to ascent. Then, at each next lower pressure, mass conservation requires that total amounts of each element $(\mathrm{O}, \mathrm{H}$, and S) remain constant. Using this constraint, the model calculates the equilibrium distribution of volatile species, which in turn affects ascent dynamics.

Redox equilibrium during magma ascent involving dissolved iron can be written such as:

$$
\mathrm{Fe}_{2} \mathrm{O}_{3}=2 \mathrm{FeO}+1 / 2 \mathrm{O}_{2}
$$


The importance of such a reaction will be dictated by the initial amount of dissolved iron oxides. It is currently not possible to include iron as a species into our thermodynamic model because the activities of $\mathrm{FeO}$ and $\mathrm{Fe}_{2} \mathrm{O}_{3}$ are not known. We thus simulated the redox effect of iron by using an empirical model ${ }^{17}$. Runs under typical storage conditions of arc rhyolites $\left(\leq 1 \mathrm{wt} \%\right.$ total iron and $f \mathrm{O}_{2}$ between NNO-1 and $\mathrm{NNO}+1, \mathrm{fO}_{2}$ being referenced to the solid buffer $\mathrm{Ni}-\mathrm{NiO}$, such that $\mathrm{NNO}+1$ means an $\mathrm{fO}_{2}$ one order of magnitude higher than NNO) show that reaction (4) partly buffers changes in $\mathrm{fO}_{2}$ when little gas is present in the reservoir $(<0.2$ unit log without changing the redox trend during ascent, see SI). In contrast, in iron-rich liquids such as basalts, the buffering capacity of iron species will be higher. Thus our results primarily apply to magmas in which the residual melt is rhyolitic, as commonly observed in arc settings. We did not consider the role of iron in crystals because the role of solid buffers as a first order mechanism controlling redox state during magma ascent can be ruled out on kinetic grounds. The lattice diffusion processes that this mechanism requires are exceedingly slow compared to those in gas or liquid phases. Similarly, for simplicity we have not investigated the role of $\mathrm{CO}_{2}$ since detailed petrologic studies of silicic magmas in arcs show them to have little or no $\mathrm{CO}_{2}$ under pre-eruptive conditions ${ }^{18}$. In general, however, introduction of $\mathrm{CO}_{2}$ will lower $\mathrm{fH}_{2} \mathrm{O}$ and thus drives our calculated values toward lower $\mathrm{fO}_{2}$ via equilibrium (1). Our assumption of equilibrium implies that the model might not capture the chemical evolution of the gas within rapidly decompressed magmas such as in Plinian eruptions, in which the contrasted diffusive kinetics of volatile species may inhibit attainment of equilibrium. Both $\mathrm{H}_{2} \mathrm{O}$ and $\mathrm{H}_{2}$ are, however, fast diffusing species relative to $\mathrm{CO}_{2}$ and S-bearing ones ${ }^{18,19}$. Thus, if physical fractionation of volatile species arises during ascent, the gas phase composition will be driven toward the system H-O (C and S species remain in the melt, such as documented for $\mathrm{S}$ for the 1991 Pinatubo eruption $^{20}$ ), which will 
exert a dominant control on the redox state of escaping gases. Our model represents thus a fundamental end-member case toward which magmas, notably those intermediate to silicic in arc settings, tend to evolve.

We have explored the following range of starting conditions typical of silicic arc $\operatorname{magmas}^{21,22}$ : an initial pressure from 2000 to 3000 bars, $\mathrm{fO}_{2}$ from $\mathrm{NNO}+2$ to NNO-0.5, bulk iron contents $\left(\mathrm{FeO}^{*}\right)$ up to $3 \mathrm{wt} \%$, bulk water contents up to $10.4 \mathrm{wt} \%$ and bulk sulphur contents up to $3 \mathrm{wt} \%$, the two latter parameters being adjusted by varying the amount of excess gas in the reservoir (up to $5 \mathrm{wt} \%{ }^{23}$ ). The conduit radius was fixed at $5 \mathrm{~m}$ for all runs. Temperature has been fixed to $825^{\circ} \mathrm{C}$, i.e. typical of rhyolite magmas ${ }^{21}$, and melt density to $2140 \mathrm{~kg} / \mathrm{m}^{3}$, though different choices will not affect the trends observed. Runs are constrained to reach atmospheric pressure at the vent, which yields initial ascent rates between 0.7 and $12 \mathrm{~m} / \mathrm{s}$. Because degassing occurs in equilibrium, changes in chemistry as a function of pressure occur regardless of ascent speed. In all cases, the simulations are carried down to atmospheric pressure though it can be anticipated that the last increments of $\mathrm{fO}_{2}$ change we compute might not be reached owing either to the inhibiting effect of viscosity at low water content ${ }^{24}$ or to gas loss once a permeability threshold is reached such that the system becomes open to gas ${ }^{25}$.

We first consider the S- and Fe-free case. All simulations performed showed essentially identical behaviour in terms of redox state evolution, i.e. the $\mathrm{fO}_{2}$ of the magma increases during ascent, the magnitude of increase being more or less dampened by the amount of free gas present in the reservoir. A representative example is shown on Figure 1, corresponding to a magma initially stored at 2000 bars, at an $\mathrm{fO}_{2}$ of NNO- 0.2 , with a melt $\mathrm{H}_{2} \mathrm{O}$ content of $5.46 \mathrm{wt} \%$ and for excess gas contents of $0.1,1$, and $5 \mathrm{wt} \%$. The simulations show that the magnitude of $\mathrm{fO}_{2}$ change increases when the amount of excess gas decreases, and can reach more than two log units for a gas-poor magma $(0.1 \mathrm{wt} \%)$. 
We now explore the case of sulphur-bearing rhyolite magma with $1 \mathrm{wt} . \%$ of total iron and stored at 2000 bar, illustrating our calculations with three different initial $\mathrm{fO}_{2}$ but similar initial dissolved sulphur contents (ca. 200-250 ppm). A magma starting at an $\mathrm{fO}_{2}$ of NNO-0.5 displays a continuous increase in its $\mathrm{fO}_{2}$ as it ascends, except in the last few hundred bars where a reversal in $\mathrm{fO}_{2}$ toward reduction occurs (Fig. 2). The magnitude of change is strongly dependent on the amount of gas initially present in the reservoir. At low gas content $(0.1 \mathrm{wt} \%)$, the $\mathrm{fO}_{2}$ rises by $0.7 \mathrm{log}$ unit relative to starting conditions. With 5 $\mathrm{wt} \%$ gas, the magma has a redox state nearly constant up to a pressure of 100 bars. When the starting $\mathrm{fO}_{2}$ in the reservoir is at NNO (Fig. 2), the magma undergoes oxidation only for gas-poor conditions $(0.1 \mathrm{wt} \%)$. Higher amounts of gas in the reservoir impart a reducing trend in the $\mathrm{fO}_{2}$ evolution during ascent, the final $\mathrm{fO}_{2}$ differing by almost one log unit from the initial value for an initial gas content of $5 \mathrm{wt} \%$. When the initial $\mathrm{fO}_{2}$ in the reservoir is at $\mathrm{NNO}+1.5$, the magma undergoes a significant reduction during ascent regardless of its initial gas content (Fig. 2). In this case, the drop in $f_{2}$ may exceed $1.5 \log$ units at near atmospheric conditions for gas rich conditions.

The change in $\mathrm{fO}_{2}$ during decompression is accompanied by dramatic changes in gas phase composition (Fig. 3). Our calculated $\mathrm{H}_{2} \mathrm{~S} / \mathrm{SO}_{2}$ ratios fall in the range 0.1-10, which is comparable to that of volcanic gases measured at convergent settings for silicic to intermediate magmas ${ }^{26}$ (Fig. 3). Clearly, a variety of $\mathrm{H}_{2} \mathrm{~S} / \mathrm{SO}_{2}$ ratio can be produced from magmas having common initial redox states but different amounts of gases. Conversely, a given $\mathrm{H}_{2} \mathrm{~S} / \mathrm{SO}_{2}$ ratio may be produced from a wide range of starting redox conditions. For instance a $\mathrm{H}_{2} \mathrm{~S} / \mathrm{SO}_{2}$ ratio of about one can be produced from a magma initially stored at $\mathrm{NNO}+1.5$ with $5 \mathrm{wt} \%$ gas, or from a magma initially at NNO-0.5 with $0.1 \mathrm{wt} \%$ gas (Fig. 3a). Thus, anticipating the $\mathrm{H}_{2} \mathrm{~S} / \mathrm{SO}_{2}$ ratio of gases emanating from a given reservoir would require knowing not only the reservoir $\mathrm{fO}_{2}$ but also the amount of free gas present in the 
reservoir and the depth at which gas and melt are physically separated. Although such a rich behaviour precludes a simple explanation for each trend calculated, a sensitivity analysis of our model suggests that water exsolution plays an important role in oxidizing the system, and that, on the other hand, the complex pressure dependence of the redox equilibria (1)-(3) contribute to the reducing trends. Our findings have thus obvious implications for the use of volcanic gases as a monitoring tool of volcanic activity. They also illustrate the important role of sulphur. Magmas poor in sulphur or in which reactions involving sulphur are kinetically inhibited are likely to undergo a significant increase in their redox state during ascent.

The above results show that the redox state that magma records at depth does not necessarily mirror that of its escaping gases, in particular when they are released from levels shallower than the main reservoir. Thus, from a broader perspective, our findings have implications for our understanding on how past volcanic activity may have impacted Earth's atmosphere. Current models of the evolution of atmospheric oxygen implicitly assume that the redox state of magmatic rocks can be taken as equal to that of their outgassed products ${ }^{6,7}$. Our calculations show that, for silicic magmas, this assumption holds true only under a restricted set of conditions (for instance a magma starting at NNO0.5 with $1 \mathrm{wt} \%$ gas, Fig. 2). Oxidized silicic magmas are particularly prone to redox change during ascent. A recent study ${ }^{10}$ has stressed the difference in $\mathrm{fO}_{2}$ retrieved from volcanic gas ${ }^{11}$ and volcanic glass ${ }^{12}$ at Kilauea volcano: the basaltic glass, which is fully degassed, records an $\mathrm{fO}_{2}$ lower by $1.2 \mathrm{log}$ unit than the gases. Although our model is calibrated on Fe-poor liquids, its predictions are qualitatively in accord with such an observation which suggests that even for basaltic magmas in non-arc settings, redox change during degassing may occur ${ }^{27}$. The corollary is that the iron redox state of a magma may significantly differ from its source, in contrast to conventional wisdom ${ }^{28}$. Altogether, 
this suggests that equating the redox state and composition of present day volcanic gases to those emitted in the geologic past ${ }^{6}$ may not be a correct assumption. 


\section{References}

1. Wilson, L., Sparks, R.S.J. \& Walker, G.P.L. Explosive volcanic eruptions. IV. The control of magma properties and conduit geometry on eruption column behavior. Geophys. J.R. Astron. Soc. 63, 117-148 (1980)

2. Papale, P. Strain-induced magma fragmentation in explosive eruptions. Nature 397, 425428 (1999).

3. Huppert, H.E. \& Woods, A.W. The role of volatiles in magma chamber dynamics. Nature 420, 493-495 (2002).

4. Gonnerman, H.M. \& Manga, M. Explosive volcanism may not be an inevitable consequence of magma fragmentation. Nature 426, 432-435 (2003).

5. Burgisser, A. \& Gardner, J. Experimental constraints on degassing and permeability in volcanic conduit flow. Bull. Volc. 67, 42-56 (2005).

6. Holland, H.D. Volcanic gases, black smokers and the great oxidation event. Geochim. Cosmochim. Acta 66, 3811-3826 (2002).

7. Kasting, J.F., Eggler, D.H. \& Raeburn, S.P. Mantle redox evolution and the oxidation state of the atmosphere. J. Geol. 101, 245-257 (1993).

8. Gerlach, T.M. Comment on paper «Morphology and compositions of spinel in Pu'u'O’o lava (1996-1998), Kilauea volcano, Hawaii'-enigmatic discrepancies between lava and gas-based $\mathrm{fO}_{2}$ determinations of Pu'u'O'o lava, J. Volcanol. Geotherm. Res. 134, 241-244 (2004).

9. Gerlach, T.M. Oxygen buffering of Kilauea volcanic gases and the oxygen fugacity of Kilauea basalt. Geochim. Cosmochim. Acta 57, 795-814 (1993).

10. Roeder, P.L., Thornber, C. Proustovetov, A. \& Grant, A. Morphology and composition of spinel in Pu'u'O'o lava (1996-1998), Kilauea volcano, Hawaii. J. Volcanol. Geotherm. Res. 123, 245-265 (2003). 
11. Moretti, R. \& Papale, P. On the oxidation state and volatile behavior in multicomponent gas-melt equilibria. Chem. Geol. 213, 265-280 (2004)

12. Clemente, B., Scaillet, B. \& Pichavant, M. The solubility of sulphur in hydrous rhyolitic melts. J. Petrol. 45, 2171-2196 (2004).

13. Gaillard, F., Schmidt, B. Mackwell, S. \& McCammon, C. Rate of hydrogen-iron redox exchange in silicate melts and glasses. Geochim Cosmochim. Acta 67, 2427-2441 (2003).

14. Holloway, J.R. Thermodynamic modelling of geological materials: minerals, fluids and melts. Reviews in Mineralogy (eds. Carmichael, I.S.E. \& Eugster, H.P.) 17, 211-233 (Mineralogical Society of America, Book Crafters, Chelsea, MI, 1987).

15. Scaillet, B. \& Pichavant, M. Role of $\mathrm{fO}_{2}$ on fluid saturation in basalts. Nature, doi $10 / 1038(2004)$

16. Shi, P.F. \& Saxena, F.K. Thermodynamic modeling of the C-H-O-S fluid system. Amer. Mineral. 77, 1038-1049 (1992).

17. Kress, V.C., \& Carmichael, I.S.E. The compressibility of silicate liquids containing $\mathrm{Fe} 2 \mathrm{O} 3$ and the effect of composition, temperature, oxygen fugacity and pressure on their redox states. Contrib. Mineral. Petrol. 108, 82-92 (1991).

18. Wallace, P. Volatiles in subduction zone magmas: concentrations and fluxes based on melt inclusion and volcanic gas data. J. Volcanol. Geotherm. Res. 140, 217-240 (2004).

19. Watson, E.B. (1994). Diffusion in volatile-bearing magmas. In Carroll, M.R. \& Holloway, J.R (eds), Volatiles in magmas, Rev. Mineral. 30, 371-412.

20. Westrich, H.R. \& Gerlach, T.M. Magmatic gas source for the stratospheric $\mathrm{SO}_{2}$ cloud from the June 15, 1991 eruption of Mount Pinatubo. Geology 20, 867-870 (1992).

21. Scaillet, B. \& Pichavant, M. Experimental constraints on volatile abundances in arc magmas and their implications fro degassing processes, in Volcanic degassing, $\mathrm{C}$. Oppenheimer, D. Pyle \& J. Barclay (eds.) Geol. Soc. Spec. Pub. 213, 23-52 (2003) 
22. Scaillet, B., Luhr, J. \& Carroll, M.R. Petrological and volcanological constraints on volcanic sulfur emissions to the atmosphere. In Volcanism and the Earth's Atmosphere, A. Robock \& C. Oppenheimer (eds.), Geophys. Monog. 139, 11-40 (2003).

23. Wallace, P., Anderson, A.T. \& Davis, A.M. Quantification of pre-eruptive exsolved gas contents in silicic magmas. Nature 377, 612-616 (1995).

24. Gardner, J.E., Hilton, M. \& Carroll, M.R. Bubble growth in highly viscous silicate melts during continuous decompression from high pressure, Geochim. Cosmochim. Acta 64, 1473-1483 (2000).

25. Eichelberger, J.C., Carrigan, C.R., Westrich, H.R. \& Price, R.H. Non explosive silicic volcanism. Nature 323, 598-602 (1986).

26. Symonds, R.B., Rose, W.I., Bluth, G.J.S., and Gerlach, T.M. Volcanic-gas studies: methods, results, and applications, in: Carroll, M.R., and Holloway, J.R. (eds) Volatiles in magmas, Reviews in Mineralogy, v. 30, p. 1-66 (1994).

27. Mathez, E.A. Influence of degassing on oxidation states of basaltic magmas. Nature 310, 371-375 (1984).

28. Carmichael, I.S.E. The redox states of basic and silicic magmas: a reflexion of their source regions. Contrib. Mineral. Petrol. 106, 129-141 (1991).

29. Holtz, F., Behrens, H., Dingwell, D.B. \& Johannes, W. $\mathrm{H}_{2} \mathrm{O}$ solubility in haplogranitic melts: compositional, pressure and temperature dependence. Am. Mineral. 80, 94-108 (1995).

Supplementary Information is linked to the online version of the paper at www.nature.com/nature 


\section{Acknowledgements}

We thank M. Rutherford, P. Wallace, and an anonymous reviewer for critical comments that helped us to improve our model. A.B. acknowledges support from the Swiss National Science Foundation.

\section{Authors Information}

Reprints and permissions information is available at www.nature.com/reprints. The authors declare no competing financial interests and contributed equally to this work. Correspondence and requests for materials should be addressed to A.B. (burgisse@cnrsorleans.fr)

\section{Figure Captions}

Figure 1: Fundamental relationship between magma ascent and magma redox state, for a rhyolite magma coexisting with a $\mathrm{H}-\mathrm{O}$ gas. From gas content and composition at depth, the coupled model of conduit flow calculates the evolution of the physical and chemical conditions of the ascending magma. The effect of equilibrium degassing is a systematic increase in $\mathrm{fO}_{2}$ (referenced to the NNO buffer) with shallower pressure. Representative cases for 3 initial values of exsolved volatiles with an $\mathrm{fH}_{2}$ initially fixed at 10 bar.

Figure 2: Fundamental relationship between magma ascent and magma redox state, for a rhyolite magma coexisting with a H-O-S gas. Effect of initial redox state on its evolution during decompression. Representative cases for 3 starting values of exsolved volatiles with an $\mathrm{fH}_{2} \mathrm{O}$ initially fixed at 1000 bar. Initial redox state was achieved by varying $f \mathrm{H}_{2}\left(\Delta \mathrm{NNO}-0.5: f \mathrm{H}_{2}=10, \Delta \mathrm{NNO}+0: f \mathrm{H}_{2}=5.38, \Delta \mathrm{NNO}-1.5\right.$ : $\left.f \mathrm{H}_{2}=1\right)$ 
Figure 3: Evolution of the composition of an H-O-S gas phase during ascent of a rhyolite magma. A) Effect of the initial redox state on the ratio $\mathrm{H}_{2} \mathrm{~S} / \mathrm{SO}_{2}$ for 3 starting values of $\mathrm{fO}_{2}$, each with three different gas contents (same initial conditions as in Fig. 2). Natural range observed on active volcanoes in convergent settings ${ }^{26}$, and range calculated by phase equilibra experiments ${ }^{21}$ are also shown. B) Evolution of the gas composition for a magma oxidized at depth $(\Delta \mathrm{NNO}+1.5,0.1 \mathrm{wt} \%$ gas $)$. C) Evolution of the gas composition for a magma reduced at depth ( $\Delta \mathrm{NNO}-0.5,0.1 \mathrm{wt} \%$ gas). Contents of $\mathrm{O}_{2}$ are too low ( $\left.<10 \mathrm{ppm}\right)$ to be displayed 
Table 1: Solubility constants

species $\quad a_{i} \quad b_{i}$

$\begin{array}{ccc}\mathrm{H}_{2} \mathrm{O} & 1.06310^{-3} & 0.5399 \\ \mathrm{H}_{2} & 3.40010^{-7} & 1.2800 \\ \mathrm{SO}_{2} & 1.63210^{-10} & 1.3789 \\ \mathrm{H}_{2} \mathrm{~S} & 8.23910^{-6} & 0.5145 \\ \mathrm{O}_{2} & 0 & - \\ \mathrm{S}_{2} & 0 & -\end{array}$

The $a_{i}$ and $b_{i}$ parameters were determined by fitting experimental solubility data of corresponding species to an empirical equation of the form $w_{\mathrm{i}}=\mathrm{a}_{\mathrm{i}} f_{\mathrm{i}}$. Wi . We have used data from ref . 12 for sulphur bearing species, ref. 13 for hydrogen and ref. 29 for water. 


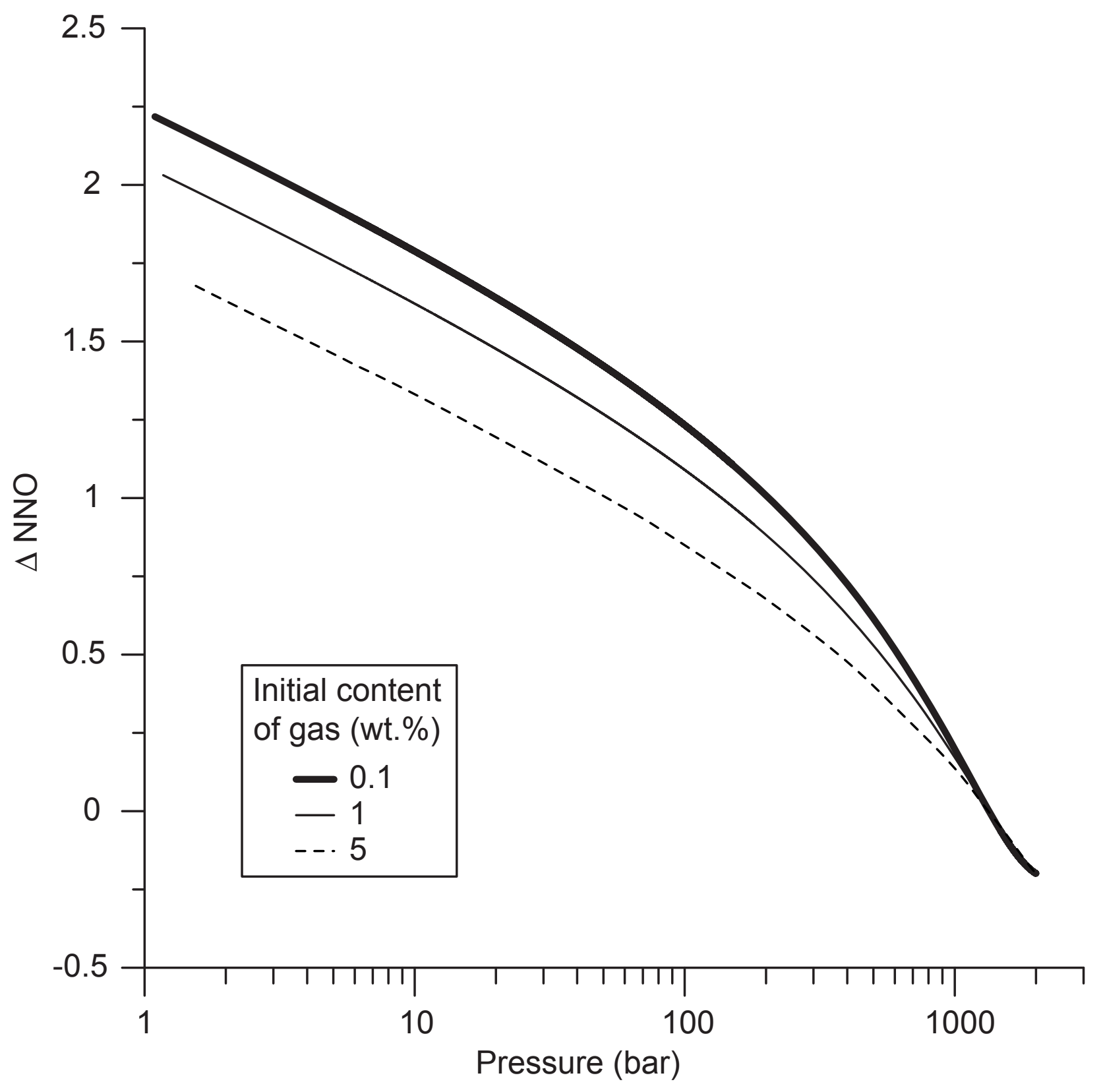

FIGURE 1 


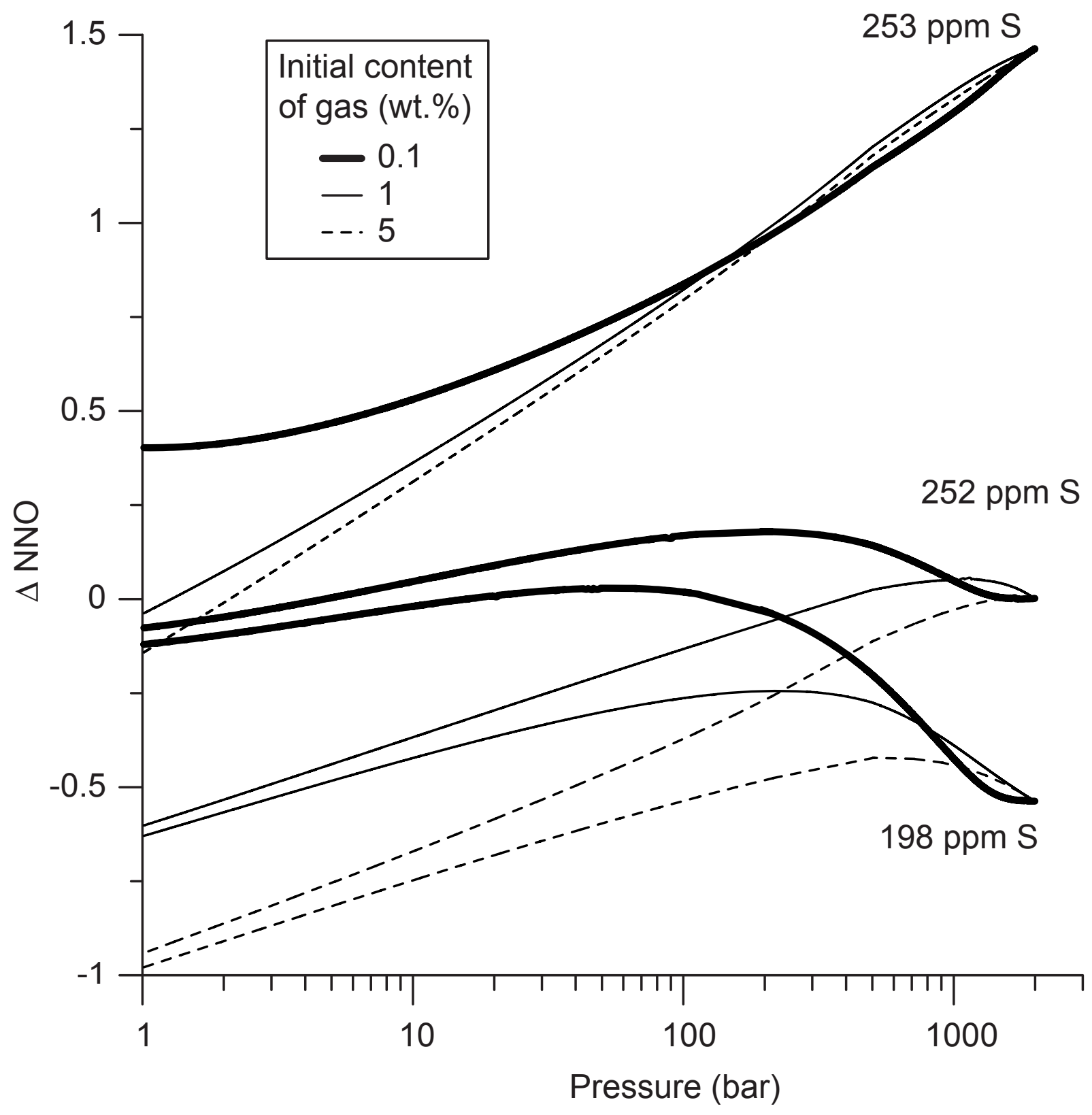

FIGURE 2 

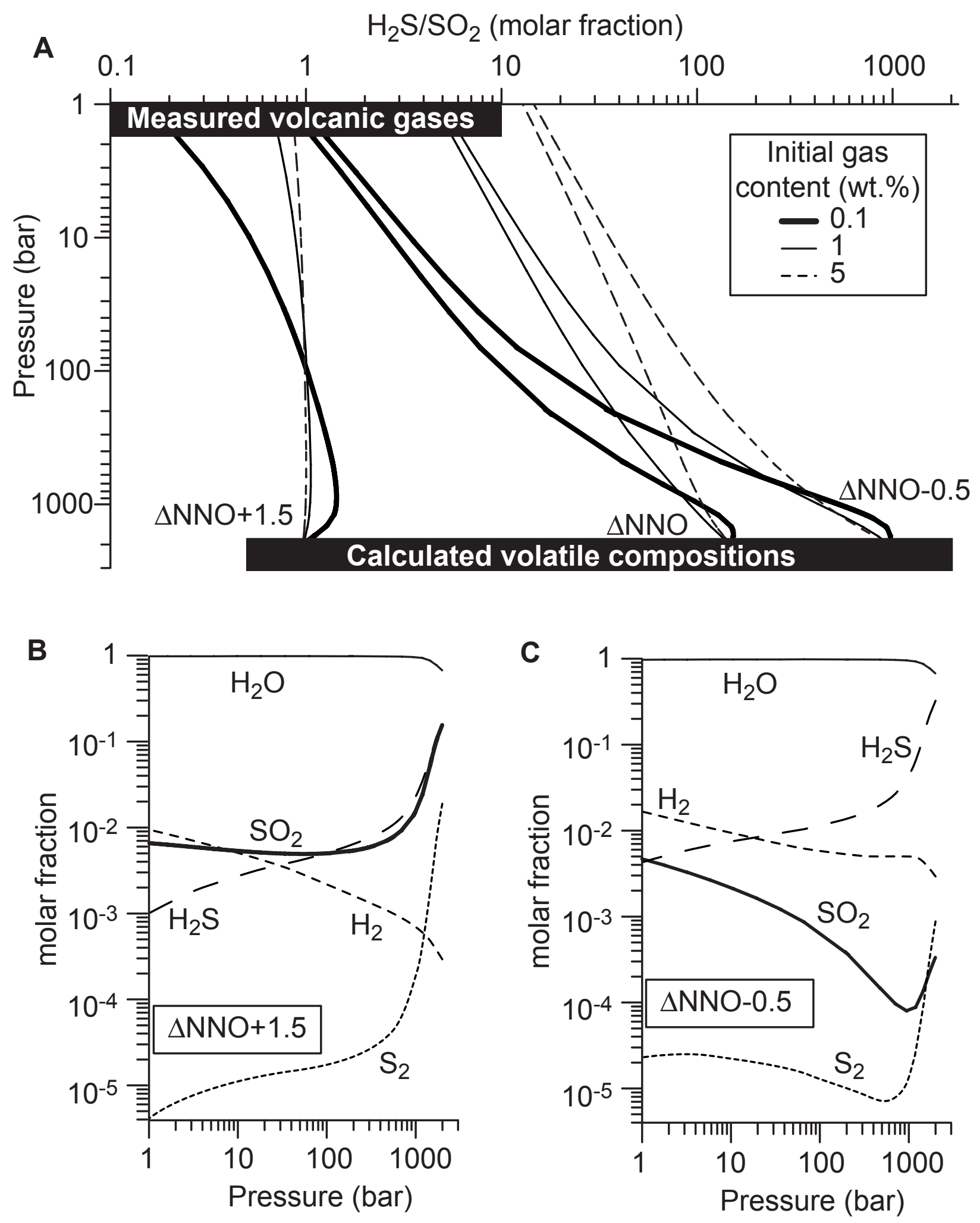

FIGURE 3 


\section{Supplementary Information}

A coupled chemical-physical model of magma ascent allowed us to establish the relationship between the ascent of magma and its redox state. The chemistry formulation is based on that of Clemente et al. (2004), whereas the physical part is based on Burgisser and Gardner (2005). The gas phase is composed of $n$ species, each with a molar fraction $m_{i}$ :

$$
\sum_{i=1}^{n} m_{i}=1
$$

Conversion between molar fraction and weight fraction is:

$$
x_{i}=\frac{m_{i} M_{i}}{\sum_{j} m_{j} M_{j}}
$$

where $M_{i}$ are molecular weights of each species. The total weight fraction of each species $\left(w_{T i}\right)$ is the sum of its exsolved part and its dissolved part:

$$
w_{T i}=w_{g T} x_{i}+a_{i}\left(f_{i}\right)^{b_{i}}
$$

where $w_{g T}$ is total gas weight fraction, $a_{i}$ and $b_{i}$ are solubility constants determined experimentally (Table 1), and $f_{i}$ is species fugacity. We assume the gas phase is an ideal mixture of non-ideal gases, which yields the following expression for fugacities:

$$
f_{i}=\gamma_{i} m_{i} P
$$

where $P$ is total pressure, and coefficients $\gamma_{i}$ are calculated at each pressure step following Shi and Saxena (1992). Using (2) and (4), (3) can be written as:

$$
w_{T i}=w_{g T} \frac{m_{i} M_{i}}{\sum m_{j} M_{j}}+a_{i}\left(\gamma_{i} m_{i} P\right)^{b_{i}}
$$

\section{System H-O}

The gas phase is composed of 3 species $\left(\mathrm{H}_{2} \mathrm{O}, \mathrm{H}_{2}\right.$, and $\left.\mathrm{O}_{2}\right)$ that are in equilibrium at all times:

$$
K_{1}=\left(f H_{2} \mathrm{O}\right)\left(f \mathrm{H}_{2}\right)^{-1}\left(f \mathrm{O}_{2}\right)^{-1 / 2}
$$

where $K_{1}$ is an equilibrium constant calculated according to Robie et al. (1979). Replacing the fugacities by their expressions in (4) yields:

$$
K_{1}=\left(\gamma_{\mathrm{H} 2 \mathrm{O}} m_{\mathrm{H} 2 \mathrm{O}}\right)\left(\gamma_{\mathrm{H} 2} m_{\mathrm{H} 2}\right)^{-1}\left(\gamma_{\mathrm{O} 2} m_{\mathrm{O} 2} P\right)^{-1 / 2}
$$

Initially, $w_{g T}$ and $f \mathrm{H}_{2}$ are set at a given pressure and temperature at depth. The molar composition of the gas phase can be determined by using (4) to calculate $m_{\mathrm{H} 2}$, (1) and (7) to calculate $m_{\mathrm{O} 2}$, and (1) to calculate $\mathrm{m}_{\mathrm{H} 2 \mathrm{O}}$. When decompression occurs, mass conservation requires that total amounts of oxygen and hydrogen of the system remain constant. Total weight percents of atomic oxygen $\left(w_{T O}\right)$ and atomic hydrogen $\left(w_{T H}\right)$ can be determined from initial gas composition by using:

$$
w_{T O}=M_{O}\left(\frac{w_{T H 2 O}}{M_{H 2 O}}+2 \frac{W_{T O 2}}{M_{O 2}}\right)
$$




$$
w_{T H}=M_{H}\left(2 \frac{w_{T H 2 O}}{M_{H 2 O}}+2 \frac{W_{T H 2}}{M_{H 2}}\right)
$$

and replacing the total amount of each species $w_{T i}$ in (8) by their expressions in (5):

$$
\begin{gathered}
\frac{w_{T O}}{M_{O}}=\frac{w_{g T} m_{H 2 O}}{\sum m_{j} M_{j}}+\frac{a_{H 2 O}\left(\gamma_{H 2 O} m_{H 2 O} P\right)^{b_{H 2 O}}}{M_{H 2 O}}+2 \frac{w_{g T} m_{O 2}}{\sum m_{j} M_{j}} \\
\frac{w_{T H}}{2 M_{H}}=\frac{w_{g T} m_{H 2 O}}{\sum m_{j} M_{j}}+\frac{a_{H 2 O}\left(\gamma_{H 2 O} m_{H 2 O} P\right)^{b_{H 2 O}}}{M_{H 2 O}}+\frac{w_{g T} m_{H 2}}{\sum m_{j} M_{j}}+\frac{a_{H 2}\left(\gamma_{H 2} m_{H 2} P\right)^{b_{H 2}}}{M_{H 2}}
\end{gathered}
$$

When total pressure decreases, the molar fractions $\left(m_{\mathrm{H} 2 \mathrm{O}}, m_{\mathrm{H} 2}\right.$, and $\left.m_{\mathrm{O} 2}\right)$ and the total amount of volatiles exsolved $\left(w_{g T}\right)$ are constrained by mass conservation, chemical equilibrium, and solubility laws embedded in the four equations (1), (7), (9a), and (9b). Using (1) and (7), $m_{\mathrm{H} 2 \mathrm{O}}$ and $m_{\mathrm{H} 2}$ can be expressed as a function of $m_{\mathrm{O} 2}$ :

$$
\begin{aligned}
& m_{\mathrm{H} 2 \mathrm{O}}=\left(1-m_{\mathrm{O} 2}\right)\left(1+\frac{\gamma_{\mathrm{H} 2 \mathrm{O}}}{K_{1} \gamma_{\mathrm{H} 2} \sqrt{m_{\mathrm{O} 2} \gamma_{\mathrm{O} 2} P}}\right)^{-1} \\
& m_{\mathrm{H} 2}=1-m_{\mathrm{O} 2}-m_{\mathrm{H} 2 \mathrm{O}}
\end{aligned}
$$

Combining (9a) and (9b) as to eliminate $w_{g T}$ and using (10) yields an expression for $m_{\mathrm{O} 2}$ that we solved with an iterative procedure to find its roots:

$$
\begin{aligned}
& \frac{w_{T H}}{2 M_{H}\left(1-m_{O 2}\right)}-\frac{w_{T O}}{M_{O}\left(m_{H 2 O}+2 m_{O 2}\right)}= \\
& \frac{a_{H 2}\left(\gamma_{H 2} m_{H 2} P\right)^{b_{H} 2}}{M_{H 2}\left(1-m_{O 2}\right)}+\frac{a_{H 2 O}\left(\gamma_{H 2 O} m_{H 2 O} P\right)^{b_{H 2 O}}}{M_{H 2 O}}\left(\frac{1}{1-m_{O 2}}-\frac{1}{m_{H 2 O}+2 m_{O 2}}\right)
\end{aligned}
$$

Because $m_{\mathrm{H} 2 \mathrm{O}}$ is on the order of $10^{-1}$ and $m_{\mathrm{O} 2}$ is usually $<10^{-10}$, it is essential to carry all calculations with sufficient numerical precision. We used a precision of 20 digits, which ensured that errors on $m_{\mathrm{O} 2}$ values were $<0.1 \%$ when $m_{\mathrm{O}_{2}}>10^{-17}$.

\section{System H-O-S}

The gas phase is composed of 6 species $\left(\mathrm{H}_{2} \mathrm{O}, \mathrm{H}_{2}, \mathrm{O}_{2}, \mathrm{~S}_{2}, \mathrm{H}_{2} \mathrm{~S}\right.$ and $\left.\mathrm{SO}_{2}\right)$ that are in equilibrium at all times:

$$
\begin{aligned}
& K_{1}=\left(f \mathrm{H}_{2} \mathrm{O}\right)\left(f \mathrm{H}_{2}\right)^{-1}\left(f \mathrm{O}_{2}\right)^{-1 / 2} \\
& K_{2}=\left(f \mathrm{SO}_{2}\right)\left(f S_{2}\right)^{-1 / 2}\left(f \mathrm{O}_{2}\right)^{-1} \\
& K_{3}=\left(f \mathrm{H}_{2} S\right)\left(f \mathrm{O}_{2}\right)^{1 / 2}\left(f S_{2}\right)^{-1 / 2}\left(f \mathrm{H}_{2} \mathrm{O}\right)^{-1}
\end{aligned}
$$

where $K_{1}, K_{2}$, and $K_{3}$ are equilibrium constants (Ohomoto and Kerrick, 1977; Robie et al., 1979). The total weight percents of atomic oxygen $\left(w_{T O}\right)$, atomic hydrogen $\left(w_{T H}\right)$, and atomic sulfur $\left(w_{T S}\right)$ are given by:

$$
w_{T O}=M_{O}\left(\frac{w_{T H 2 O}}{M_{H 2 O}}+2 \frac{w_{T O 2}}{M_{O 2}}+2 \frac{w_{T S O 2}}{M_{S O 2}}\right)
$$




$$
\begin{aligned}
& w_{T H}=M_{H}\left(2 \frac{w_{T H 2 O}}{M_{H 2 O}}+2 \frac{w_{T H 2}}{M_{H 2}}+2 \frac{w_{T H 2 S}}{M_{H 2 S}}\right) \\
& w_{T S}=M_{S}\left(2 \frac{w_{T S 2}}{M_{S 2}}+\frac{w_{T H 2 S}}{M_{H 2 S}}+\frac{w_{T S O 2}}{M_{S O 2}}\right)
\end{aligned}
$$

Like the $\mathrm{H}-\mathrm{O}$ system, the resolution is carried out in two steps. First, $w_{g T}, f \mathrm{H}_{2} \mathrm{O}$ and $\mathrm{fH}_{2}$ are set at depth so that the composition of the gas phase and the total amounts of each element could be determined. Second, each time pressure decreases, mass conservation (1) and (13), chemical equilibrium (12), and solubility laws (5) are used jointly to solve for the seven unknowns (molar fractions $m_{i}$ and the total gas weight fraction $w_{g T}$ ).

\section{Effects of Iron}

When there is iron dissolved in the melt, the following redox reaction occurs:

$$
\mathrm{FeO}+\frac{1}{2} \mathrm{O}_{2}=\mathrm{Fe}_{2} \mathrm{O}_{3}
$$

It is currently not possible to include the redox effects of iron into our thermodynamic model because the activities of $\mathrm{FeO}$ and $\mathrm{Fe}_{2} \mathrm{O}_{3}$ dissolved into a rhyolitic melt are not known. It is, however, possible to simulate such effects by using an empirical model that links, at constant temperature, the molar ratio of $\mathrm{FeO}$ and $\mathrm{Fe}_{2} \mathrm{O}_{3}$ to the oxygen fugacity (Kress and Carmichael, 1991):

$$
\ln \left(\frac{m_{\mathrm{Fe} 2 \mathrm{OO}}}{m_{\mathrm{FeO}}}\right)=a_{K C} \ln \left(f O_{2}\right)+\frac{b_{K C}}{T}+c_{K C}+\sum_{k} d_{K C k} m_{k}+f_{K C} \frac{P}{T}+h_{K C} \frac{P^{2}}{T}
$$

where $k$ is one of $\left(\mathrm{FeO}^{*}, \mathrm{Al}_{2} \mathrm{O}_{3}, \mathrm{CaO}, \mathrm{Na}_{2} \mathrm{O}\right.$, and $\left.\mathrm{K}_{2} \mathrm{O}\right), m_{k}$ is the total molar fraction of these species, and $a_{K C}, b_{K C}, c_{K C}, d_{K C} k, f_{K C}, h_{K C}$ are constants given in Kress and Carmichael (1991). We calculated the redox effect of iron in the H-O-S system by using (15) and keeping track of the total amounts of $\mathrm{Fe}\left(w_{T F e}\right)$, oxygen in the $\mathrm{FeO}$ and $\mathrm{Fe}_{2} \mathrm{O}_{3}$ form $\left(w_{T O}(\mathrm{Fe})\right)$, and oxygen in the $\mathrm{O}_{2}, \mathrm{H}_{2} \mathrm{O}$, and $\mathrm{SO}_{2}$ form $\left(w_{T O}\right)$.

Because the relation (14) contains the total molar fraction of several oxides and our mass balance (13) is in weight fraction, conversions between the two units are needed, and the total composition of the melt should be known. Thus, we fixed the total weight fraction of 9 major oxides of a typical rhyolite (in wt\%: $\mathrm{SiO}_{2}=77.44$, $\mathrm{Al}_{2} \mathrm{O}_{3}=12.88, \mathrm{TiO}_{2}=0.07, \mathrm{CaO}=0.6, \mathrm{Na}_{2} \mathrm{O}=4.14, \mathrm{~K}_{2} \mathrm{O}=4.76, \mathrm{MgO}=0.03, \mathrm{MnO}=0.05$, $\mathrm{P}_{2} \mathrm{O}_{5}=0.03$ ). These initial values add up to $100 \%$, and need to be corrected to take in account the amounts of volatiles and iron. For each run, initial quantities of $\mathrm{FeO}^{*}$ ( $\left.w_{T F e} *\right), w_{g T}, f \mathrm{H}_{2} \mathrm{O}$ and $f \mathrm{H}_{2}$ are set at depth. Using the same procedure as described in "H-O-S system", total amounts of sulphur, hydrogen, and oxygen in the $\mathrm{O}_{2}, \mathrm{H}_{2} \mathrm{O}$, and $\mathrm{SO}_{2}$ form can be calculated. The initial amount of oxygen in the $\mathrm{FeO}$ and $\mathrm{Fe}_{2} \mathrm{O}_{3}$ form is not known and should be determined using the empirical equation (14). Thus, the initial quantities of the 9 major oxides are normalized so that the 9 oxides, plus the volatiles species $\left(w_{T O}, w_{T S}, w_{T H}\right)$, plus the total iron $\left(w_{T F e O}\right)$ add up to $100 \%$. Then the total molar fraction of $\mathrm{FeO}^{*}, \mathrm{Al}_{2} \mathrm{O}_{3}, \mathrm{CaO}, \mathrm{Na}_{2} \mathrm{O}$, and $\mathrm{K}_{2} \mathrm{O}$ are calculated using: 


$$
m_{i}=\frac{w_{T i}}{M_{i}} \frac{1}{\sum_{j} \frac{w_{T j}}{M_{j}}}
$$

The total amounts of iron and oxygen fixed by the iron can be expressed as:

$$
\begin{aligned}
& m_{\mathrm{Fe}}=m_{\mathrm{FeO}}+2 m_{\mathrm{Fe} 2 \mathrm{O} 3} \\
& m_{\mathrm{O}(\mathrm{Fe})}=m_{\mathrm{FeO}}+3 m_{\mathrm{Fe} 2 \mathrm{O} 3}
\end{aligned}
$$

From (15), we define that

$$
\frac{m_{\mathrm{Fe} 2 \mathrm{O} 3}}{m_{\mathrm{FeO}}}=K C
$$

Combining (17)-(18), we get:

$$
m_{O(F e)}=m_{F e} \frac{1+3 K C}{1+2 K C}
$$

Using $w_{T F e}=\frac{w_{T F e O^{*}}}{M_{\mathrm{FeO}}} M_{\mathrm{Fe}}$ and the conversion (16) for $w_{T F e}$ and $w_{T O(F e)}$ yields the total amount of oxygen fixed by the iron:

$$
w_{T O(F e)}=M_{O} \frac{w_{T F e}}{M_{F e}} \frac{1+3 K C}{1+2 K C}
$$

The mass balance can now be rigorously carried out by adding the 9 oxides, the volatiles species $\left(w_{T O}, w_{T S}\right.$, and $\left.w_{T H}\right)$, the total iron $\left(w_{T F e}\right)$ and the oxygen fixed by the iron $\left(w_{T O(F e)}\right)$. The total molar fractions $m_{k}$ can be updated using (16) and are used in (15) for the rest of the simulation. Because the system is closed, all the quantities involved in the mass balance, except $w_{T O}$ and $w_{T O}(\mathrm{Fe})$, are considered constant. The reaction (14) imposes an exchange of oxygen between that locked in the Fe-bearing species and that involved in the H-O-S redox reactions. The sum $w_{T O}+w_{T O}(\mathrm{Fe})=$ $w_{T O(T o t a l)}$, however, remains constant. Thus, using (20), the total amount of "free" oxygen $w_{T O}$ can be related to $\mathrm{fO}_{2}$ :

$$
w_{T O}=w_{T O(\text { Total })}-\frac{m_{F e} M_{O}}{\sum_{j} m_{j} M_{j}} \frac{1+3 K C}{1+2 K C}
$$

The numerical resolution of (21) needs to be coupled with that of the H-O-S system. For each pressure step, solving for the redox equilibrium of the volatile species (equations (1), (5), (12) and (13)) yields an $f_{2}$. This fugacity is used in (21) to obtain a new amount of "free" oxygen. The redox equilibrium of the volatile species is solved again with the updated $w_{T O}$, and the process is conducted iteratively until desired precision $\left(<10^{-5} \%\right.$ on $\left.w_{T O}\right)$ is reached. An under-relaxation factor of 0.1 is applied to the updated $w_{T O}$ to ensure convergence in 20 to 30 iterations.

Runs with $1 \mathrm{wt} \%$ of total iron under typical storage conditions of arc rhyolites $\left(\mathrm{fO}_{2}\right.$ between NNO-0.5 and $\left.\mathrm{NNO}+1.5\right)$ show that the buffering capacity of iron is limited to less than 0.2 unit log compared to the $\mathrm{S}-\mathrm{O}-\mathrm{H}$ system when little gas is present in the reservoir, and becomes insignificant when more gas is present in the reservoir (Fig. SI-1). Under such storage conditions, iron does not change the redox 
evolution of the magma with pressure. Similarly, the $\mathrm{H}_{2} \mathrm{~S} / \mathrm{SO}_{2}$ ratio changes by less than 0.2 log units when little gas is present in the reservoir and is unaffected by iron when the reservoir hosts a large amount of gas.
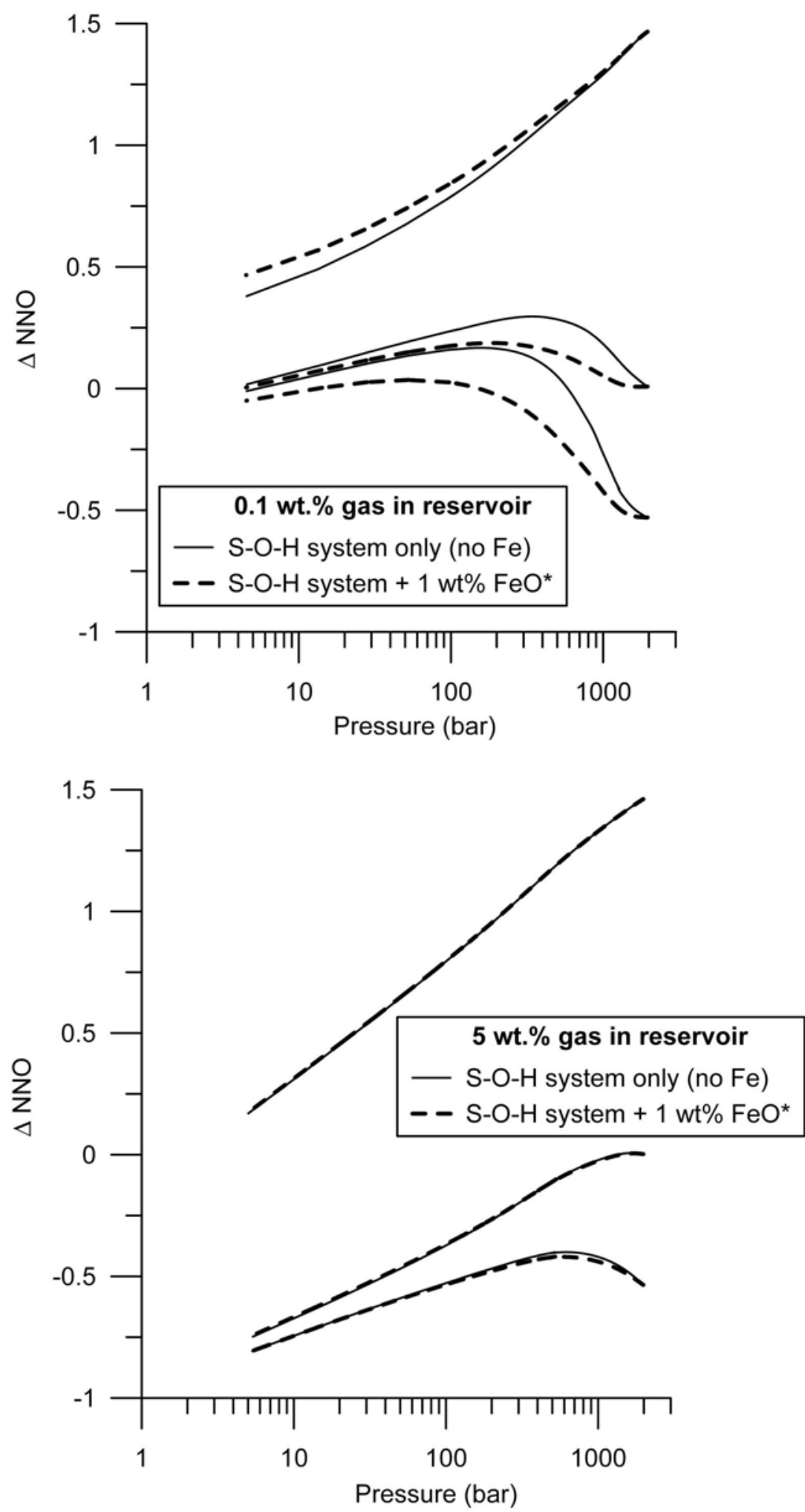

Figure SI-1: Effect of dissolved iron on the redox evolution of an ascending rhyolite. Stippled lines are runs with 1 wt.\% total iron (FeO*) and solid lines are runs with no iron. Upper graph runs start with 0.1 wt.\% gas at depth and lower graph runs start with $5 \mathrm{wt} \%$ gas at depth. 


\section{Physical part of the model}

The conduit flow model is homogenous and one-dimensional. From mass and momentum conservation, the pressure evolution with depth $(\mathrm{dP} / \mathrm{dz})$ is given by:

$$
\frac{d P}{d z}=v^{2} \frac{d \rho}{d z}-\rho g-\frac{8 \mu v}{r^{2}}-\frac{0.0025}{r} \rho v^{2}
$$

where $v$ is magma velocity, $\rho$ is magma density, $r$ is conduit radius, and $g$ is gravity. The viscosity $\mu$ is calculated with the relationship by Hess and Dingwell (1996) for the melt and correcting for the effect of bubbles using the relationship by Dobran (1992). We note that using instead the relationship by Jaupart and Allègre (1991) for the effect of bubbles on viscosity did not change the trends caused by variations in volatile chemistry. Magma bulk density is:

$$
\frac{1}{\rho}=\frac{w_{g T}}{\rho_{g}}+\frac{1-w_{g T}}{\rho_{l}}
$$

where $\rho_{g}$ is gas density from perfect gas law, and $\rho_{l}$ is melt density. Replacing the derivative of (23) into (22) and rearranging gives:

$$
\frac{d P}{d z}=\left[A\left(\frac{w_{g T}}{M} \frac{d M}{d z}-\left(1-\frac{\rho_{g}}{\rho_{l}}\right) \frac{d w_{g T}}{d z}\right)-\rho g-\frac{8 \mu v}{r^{2}}-\frac{0.0025}{r} \rho v^{2}\right]\left[1-\frac{A w_{g T}}{P}\right]^{-1}
$$

with

$$
A=v^{2} \rho_{g}\left(w_{g T}+\left(1-w_{g T}\right) \frac{\rho_{g}}{\rho_{l}}\right)^{-2}
$$

where $M$ is the average molar mass of the gas phase:

$$
M=\sum_{i=1}^{n} x_{i} M_{i}
$$

Above fragmentation (gas volume fraction $>0.75$ ), the viscosity is that of a dusty gas (Dobran, 1992), and degassing continues.

Equation (24) is solved using a fourth-order Runge-Kutta algorithm with adjustable distance step. At each pressure step, the gas composition is calculated for the system considered (H-O or H-O-S). The terms $d M / d z$ and $d w_{g T} / d z$ in (24) are evaluated implicitly, which can be justified by the fact that they are always several orders of magnitude smaller than inertia and viscous terms. Boundary condition is either atmospheric pressure at the vent, or initial velocity at depth. In the former case, a run starts with an initial guess for the velocity at depth, and the pressure is solved for until vent is reached. Initial velocity is then changed until upper boundary condition is satisfied. Because degassing occurs in equilibrium, changes in chemistry as a function of pressure are identical for the two cases.

\section{References}

Burgisser, A., and Gardner, J.E. (2005) Experimental constraints on degassing and permeability in volcanic conduit flow, Bulletin of Volcanology, v.67, p. 42-56.

Clemente, B., Scaillet, B. \& Pichavant, M. The solubility of sulphur in hydrous rhyolitic melts. J. Petrol. 45, 2171-2196 (2004). 
Dobran, F. (1992) Nonequilibrium flow in volcanic conduits and application to the eruptions of Mt. St. Helens on May, 18, 1980, and Vesuvius in AD 79, Journal of Volcanology and Geothermal Research, v.49, p. 285-311.

Hess, K-U., and Dingwell, D.B. (1996) Viscosities of hydrous leucogranitic melts: A nonArrhenian model, American Mineralogist, v.81, p. 1297-1300.

Jaupart C, and Allègre C (1991) Gas content, eruption rate and instabilities of eruption regime in silicic volcanoes, Earth Planet Sci Lett 102:413-429

Kress, V.C., and Carmichael, I.S.E. (1991) The compressibility of silicate liquids containing Fe2O3 and the effect of composition, temperature, oxygen fugacity and pressure on their redox states, Contributions to Mineralogy and Petrology, v.108, p. 82-92.

Ohomoto, H., and Kerrick, D.M. (1977) Devolatilisation equilibria in graphitic systems, American Journal of Science, v.277, p. 1013-1044.

Robie, R.A., Hemingway, B.S., and Fisher, J.R. (1979) Thermodynamic properties of minerals and related substances at $298.15 \mathrm{~K}$ and 1 bar $\left(10^{5} \mathrm{~Pa}\right)$ pressure and at higher temperatures, US Geological Survey Bulletin 1452.

Shi, P.F. \& Saxena, F.K. (1992) Thermodynamic modeling of the C-H-O-S fluid system. Amer. Mineral. 77, 1038-1049. 